\title{
PENGELOLAAN PENILAIAN AUTENTIK KURIKULUM 2013 MATA PELAJARAN MATEMATIKA DI SMA
}

\author{
Sutama, Gilang Ary Sandy, dan Djalal Fuadi \\ Pascasarjana Magister Administrasi Pendidikan \\ gilang.ary.sandy@gmail.com
}

\begin{abstract}
The purpose of this study, there are three. (1) describe the preparation of authentic assessment instrument in mathematics. (2) Describe the implementation of authentic assessment in mathematics. (3) Describe the utilization of authentic assessment in mathematics. Qualitative research using ethnographic design. Place of research on SMA Negeri 2 Sukoharjo. When the study of the month of February 2016 until the month of August 2016. The research subjects vice principal part of the curriculum, mathematics teacher and students in class XI Ipa. Data analysis techniques with interviews, observation and documentation. Validation data by triangulation and source triangulation techniques. Data analysis with interactive techniques to process data reduction, data analysis and conclusion. The results of the study there were three. (1) Preparation of an assessment instrument performed by setting the aspects studied, formulating objectives, formulate indicators based on basic competencies, and make a minimum completeness criteria. (2) The attitude aspect assessment using observation and journals. Implementation aspects of knowledge is done with an oral test, written test and assignment. Oral test as a supporter of a written test. Assignment is done by groups or individuals. Implementation done by using the skill aspect of performance using a grading scale that accompanied the rubric. (3) The use of the results of the assessment to form positive attitudes of students, homogenize the thinking ability of students, provide information to parents, and improvements in the lesson plan.
\end{abstract}

Keyword: authentic assessment, affective aspects, kognitive aspects, psychomotor aspects

\begin{abstract}
ABSTRAK
Tujuan penelitian ini ada tiga. (1) Mendeskripsikan penyusunan instrument penilaian autentik mata pelajaran matematika. (2) Mendeskripsikan pelaksanaan penilaian autentik mata pelajaran matematika. (3) Mendeskripsikan pemanfaatan hasil penilaian autentik mata pelajaran matematika. Jenis penelitian kualitatif menggunakan desain etnografi. Tempat penelitian di SMA Negeri 2 Sukoharjo. Waktu penelitian dari bulan februari 2016 sampai dengan bulan agustus 2016. Subjek penelitian wakil kepala sekolah bagian kurikulum, guru matematika dan siswa kelas XI Ipa. Teknik analisis data dengan wawancara, observasi dan dokumentasi. Validasi data dengan triangulasi teknik dan triangulasi sumber. Analisis data dengan teknik interaktif dengan proses
\end{abstract}


reduksi data, analisis data dan penarikan kesimpulan. Hasil penelitian ada tiga. (1) Penyusunan instrumen penilaian dilakukan dengan menetapkan aspek yang diteliti, merumuskan tujuan, merumuskan indicator berdasarkan kompetensi dasar, dan membuat kriteria ketuntasan minimal. (2) Pelaksanaan penilaian aspek sikap menggunakan teknik observasi dan jurnal. Pelaksanaan aspek pengetahuan dilakukan dengan tes lisan, tes tertulis dan penugasan. Tes lisan sebagai pendukung tes tertulis. Penugasan dilakukan dengan berkelompok maupun individu. Pelaksanaan aspek keterampilan dilakukan dengan teknik unjuk kerja menggunakan skala penilaian yang disertai rubrik. (3) Pemanfatan hasil penilaian untuk membentuk sikap positif siswa, menyeragamkan kemampuan berfikir siswa, memberikan informasi kepada orangtua, dan perbaikan dalam rencana pelaksanaan pembelajaran.

Kata kunci: penilaian autentik, aspek afektif, aspek kognitif, aspek psikomotor

\section{PENDAHULUAN}

Mutu pendidikan adalah masalah yang sejak dulu senantiasa diupayakan peningkatannya oleh pemerintah. Pengendalian mutu pendidikan pada dasarnya adalah pengendalian mutu SDM (sumber daya manusia) yang berada dalam sistem tersebut. Untuk mengetahui pengendalian ini dibutuhkan informasi mengenai keadaan peserta didik, apakah ada perubahan, apakah guru berfungsi, apakah sekolah mendukung terlaksananya progam-progam pendidikan sehingga hasilnya bisa dicapai secara optimal.

Salah satu cara yang dilakukan untuk dapat mengendalikan mutu dalam pendidikan adalah dengan melakukan assessment (penilaian). Menurut Clements dan Cord dalam (Crisp, 2016) penilaian merupakan komponen penting dalam belajar dan lingkungan pembelajaran serta memiliki peran dalam mengetahui hasil pembelajaran. Proses penilaian dalam pembelajaran dilakukan untuk memperoleh data mengenai perkembangan hasil belajar peserta didik. Penilaian yang dilakukan diharapkan dapat menjadi instrument penjamin mutu, pengendalian mutu dan perbaikan mutu dalam sistem pendidikan baik secara kelas maupun sekolah.

Dalam kurikulum 2013 penilaian pembelajaran mengacu pada Permendikbud No 66 Tahun 2013 tentang standar penilaian pendidikan. Menurut (Kunandar, 2013) autentik berarti keadaan yang sebenarnya, yaitu kemampuan atau keterampilan yang dimiliki oleh peserta didik. Penggunaan penilaian autentik dikarnakan penilaian ini mampu memberi solusi dalam menggambarkan peningkatan hasil belajar peserta didik, baik dalam mengobservasi, menalar, mencoba dan membangun jejaring.

Studi tiga tahunan PISA, yang diselenggarakan oleh Organization for Economic Cooperation and Development (OECD) sebuah badan PBB yang berkedudukan di Paris pada tahun 2012, dengan fokus kemampuan siswa dalam mengidentifikasi dan memahami serta menggunakan dasar-dasar matematika yang diperlukan dalam kehidupan seharihari, menempatkan Indonesia pada posisi 64 dari 65 negara (Murtiyasa, 2015).

Berdasarkan data yang diperoleh dari PISA dapat disimpulkan bahwa pembelajaran yang sedang dilakukan sekarang belum maksimal dan kurang mendorong peserta didik untuk secara aktif mandiri. Salah satu solusi untuk menyelesaikan permasalahan ini adalah dengan 
melakukan evaluasi atau penilaian pada proses pembelajaran. Oleh sebab itu dalam kurikulum 2013 diterapkan penilaian autentik yang akan menjadi penekanan serius kepada guru dalam melakukan penilaian hasil belajar peserta didik dengan benar-benar memperhatikan segala minat, potensi dan prestasi serta komprehensif.

Tujuan penelitian ini ada tiga. (1) Mendeskripsikan penyusunan intrumen penilaian autentik di SMAN 2 Sukoharjo. (2) Mendeskripsikan pelaksanaan penilaian autentik di SMAN 2 Sukoharjo. (3) Mendeskripsikan pemanfaatan hasil penilaian autentik di SMAN 2 Sukoharjo.

\section{METODE}

Dalam penelitian ini jenis penelitiannya kualitatif. Penelitian kualitatif adalah suatu penelitian yang ditujukan untuk memahami fenomena-fenomena sosial dari perspektif participan (membuat teori), hal ini diperoleh melalui pengamatan partisipatif dalam kehidupan orang-orang yang menjadi participant (Sutama, 2015). Penelitian dilakukan di SMA Negeri 2 Sukoharjo pada kelas X dan XI IPA.

Penelitian ini dilakukan untuk menggambarkan fakta dan karakteristik objek/subjek yang di teliti yaitu pada pengelolaan penilaian autentik mata pelajaran matematika di SMAN 2 Sukoharjo. Subjek dalam penelitian ini adalah guru mata pelajaran matematika kelas 10 IPA dan kelas 11 IPA.

Teknik pengumpulan data dilakukan dengan teknik wawancara, observasi dan dokumentasi. Wawancara merupakan teknik pengumpulan informasi melalui tanya jawab kepada narasumber. Observasi merupakan pengamatan yang dilakukan terkait fenomenafenomena yang terjadi. Dokumentasi merupakan catatan peristiwa yang telah terjadi (Sugiyono, 2015)

Validitas data yang digunakan dalam penelitian ini adalah triangulasi sumber dan triangulasi teknik. Triangulasi teknik menggunakan teknik pengumpulan data yang berbeda dengan sumber data yang sama. Triangulasi sumber menggunakan sumber yang berbeda dengan teknik yang sama.

Teknik analis data dalam penelitian ini menggunakan model Miles dan Huberman, mengemukakan bahwa aktivitas dalam analisis data kualitatif dilakukan secara interaktif dan berlangsung secara terus menerus sampai tuntas, sehingga datanya sudah jenuh (Sugiyono, 2015). Aktivitas analisis data, yaitu data reduction, data dispay dan conclusion drawing/ verivication.

\section{HASIL DAN PEMBAHASAN}

\section{Penyusunan instrumen penilaian autentik mata pelajaran matematika di SMAN 2 Sukoharjo}

Penyusunan instrument penilaian autentik di lakukan pada awal semester bersamaan dengan penyusunan RPP, dan KKM. Berdasarkan hasil observasi peneliti menemukan bahwa guru melakukan beberapa langkah dalam menyusun instrument penilaian autentik kurikulum 2013 antara lain. Guru menetapkan aspek-aspek yang akan dinilai, misalkan aspek afektif (sikap), kognitif (pengetahuan), dan psikomotor (keterampilan). Tujuannya adalah agar dapat mempersiapkan serta mengetahui karakteritik dan kriteria dari masing-masing aspek 
penilaian. Dalam penelitian Almond (2010), menyatakan bahwa komponen penilaian belajar siswa terdiri dari penilaian proses belajar, penilaian keterampilan dan penilaian pemahaman yang dikombinasi dengan penggunaan teknologi.

Pada tahap ke dua guru merumuskan tujuan penilaian masing-masing aspek yang akan dilakukan. Merumuskan tujuan dari tiap aspek penilaian dengan harapan bahwa jika tujuan dari penilaian jelas dan terarah maka instrument penilaian yang akan dibuat akan benar-benar dapat dipakai untuk memetakan keadaan siswa yang sebenarnya.

Pada tahapan yang ketiga guru merumuskan indikator berdasarkan kompetensi dasar yang ada dalam silabus. Selanjutnya memilih dan menentukan teknik penilaian yang akan digunakan dalam sebuah penilaian. Teknik yang dipilih disesuaikan dengan materi pelajaran yang akan diajarkan. Tanpa teknik penilaian yang tepat maka aspek-aspek yang telah ditentukan tidak akan dapat dinilai dengan baik, hal ini dapat mengakibatkan tujuan dari sebuah penilaian tidak akan tercapai.

Hasil penelitian ini didukung oleh penelitian yang dilakukan Sutama, Sabar Narimo \& Samino (2015) penelitian menunjukkan evaluasi pembelajaran matematika pada aspek afektif terdiri dari sikap spiritual dan sosial, evaluasi dilakukan melalui observasi, jurnal guru, penilaian diri dan penilaian antar teman. Pada aspek kognitif evaluasi dilakukan dengan tes tertulis, tes lisan dan penugasan. Evaluasi pada aspek psikomotor dilakukan dengan evaluasi kinerja, proyek dan portofolio, pada aspek psikomotor evaluasi cenderung dilakukan dalam kelompok.

Guru membuat kriteria ketuntasan minimal yang menjadi tolak ukur keberhasilan suatu teknik penilaian yang dipakai. Sebab suatu instrument dapat digunakan apabila memiliki tolak ukur atau kriteria ketuntasan yang dapat menginterpestasikan hasil penilaian siswa selain itu sebuah instrument dikatakan bisa dipakai untuk menilai apabila memiliki sebuah kriteria ketuntasan, kriteria ketuntasan menjadi ukuran apakah sebuah hasil penilaian itu berhasil atau gagal.

Hasil penelitian ini didukung hasil penelitian yang dilakukan Yunus dan retnowati (2014) menyatakan bahwa guru dalam melakukan penilaian terhadap peserta didik harus memperhatikan tiga hal penting meliputi kompetensi sikap, kompetensi pengetahuan dan ketermpilan yang dilakukan secara berimbang sehingga dapat digunakan untuk menetukan posisi relative setiap peserta didik terhadap standar yang telah ditetapkan.

Hasil penelitian ini dapat dimaknai bahwa dalam menyusunan instrumen penilaian guru perlu mengetahui karakteristik apa saja yang menjadi tujuan dari sebuah penilaian yang akan dilakukan. Dari observasi yang dilakukan di SMA Negeri 2 Sukoharjo menunjukan bahwa dalam sebuah penyusunan instrument penilaian autentik guru sudah melakukan langkahlangkah dalam menyususn instrument penilaian yaitu dengan menetapkan aspek-aspek yang akan diteliti, merumuskan tujuan, merumuskan indicator berdasarkan kompetensi dasar yang ada dalam silabus, dan membuat kriteria ketuntasan minimal sebagai tolak ukur hasil penilaian.

\section{Pelaksanaan penilaian autentik mata pelajaran matematika di SMAN 2 Sukoharjo}

Pelaksanaan penilaian di SMA Negeri 2 sukoharjo dalam melaksanakan penilaian autentik kurikulum 2013 diawali dengan guru melakukan sosialisasi kepada siswa selaku 
objek peniliaian. Sosialisasi dilakukan dengan memberi penjelasan kepada siswa terkait apa saja yang akan dinilai dalam penilaian kurikulum 2013, baik itu teknik yang digunakan, skala nilai, indikator serta kriteria ketuntasannya $(\mathrm{kkm})$. Hal ini dilakukan guru agar timbul kesiapan dalam diri siswa untuk menghadapi penilaian yang akan dilakukan oleh guru. Selain itu informasi tentang kriteria dalam penilaian dapat memberi motivasi siswa dalam meningkatkan kegatan belajarnya.

Hasil penelitian diperkuat oleh penelitian Gao (2012), hasil penelitian menunjukkan dengan dilakukannya penilaian matematika berdampak positif sehingga siswa merasa adanya kesesuaian kuat terkait perencanaan pembelajaran dan transparasi tujuan dan bentuk penilaian.

Berdasarkan hasil studi dokumentasi yang dilakukan peneliti memperoleh temuan bahwa dalam pelaksaan penilaian autentik aspek sikap mata pelajaran matematika terdiri atas penilaian sikap spiritual dan sikap sosial. Aspek yang dinilai dalam sikap spiritual antara lain berdoa, mengucapkan salam, toleransi. Sedangkan dalam sikap spiritual aspek yang dinilai antara lain rasa ingin tau, percaya diri, kreatif, teliti.

Teknik penilaian yang digunakan guru matematika di SMA Negeri 2 Sukoharjo dalam menilai aspek sikap menggunakan dua teknik yang sering dipakai yaitu teknik observasi dan teknik penilaian jurnal. Dalam teknik observasi guru membuat lembar observasi sesuai dengan materi yang akan diajarkan dan di samakan dengan rancangan pelaksanaan pembelajaran. Lembar observasi sudah disiapkan di setiap RPP sehingga guru tinggal mengamati dan mengisi. Untuk teknik penilaian yang menggunakan jurnal guru melakukan penilaian secara insidental (terjadi secara kebetulan) yang artinya guru melakukan penilaian jurnal dengan mengamati tingkahlaku sswa baik di dalam kelas maupun diluar kelas.

Dari observasi yang dilakukan peneliti dalam pelaksanaan penilaian autentik kuriulum 2013 guru masih merasa kesulitan dalam melaksanakan penilaian sikap spriritual dan sikap sosial terkait materi yang diajarkan yaitu matematika. Kendala disebabkan ada indicator baik sikap spiritual dan sikap sosial yang tidak terintegrasi dengan kompetensi dasar pada mata pelajaran matematika. Sehingga guru kesulitan dalam mengkaitkannya pada lembar penilaian. hasil peneltian diperkuat oleh penelitian Retnawati, Hadi \& Nugraha (2016), hasil penelitian menunjukkan bahwa dalam penerapan kurikulum 2013 guru belum sepenuhnya memahami sistem penilaian. Guru juga kesulitan dalam mengembangkan instrument penilaian sikap, melaksanakan penilaian autentik, merumuskan indicator, merancang rubric penilaian untuk keterampilan dan mengumpulkan skor dari beberapa teknik penilaian. Selain itu guru juga tidak dapat menemukan apikasi yang layak untuk menggambarkan prestasi belajar siswa.

Pelaksanaan penilaian autentik kurikulum 2013 mata pelajaan matematika pada aspek pengetahuan, guru matematika di SMA Negeri 2 Sukoharjo meggunakan teknik tes tertulis, tes lisan dan penugasan. Teknik tes tertulis dibagi menjadi dua jenis tes tertulis yaitu, ulangan harian, dan ulangan semester. Teknik tes tertulis menggunakan bentuk soal pilihan gandan dan soal uraian. Ulangan harian dilakukan guru apabila KD tertentu telah selesai diajarkan. Dalam pelaksanaan ulangan harian guru terlebih dahulu menginformasikan kepada siswa tentang materi yang akan diujikan. Hal ini dilakukan agar ada kesiapan siswa dalam melaksanakan ulangan yang akan dihadapi sehingga hasil yang didapat dapat menjadi baik. untuk ulangan semester dilakukan oleh guru di akhir semester dengan menggunakan bentuk soal pilihan 
berganda.

Tes lisan hanya digunakan oleh guru untuk melakukan perbaikan setelah diadakannya tes tertulis (tes tertulis) tujuannya adalah untuk membantu siswa dalam memahami soal dan membimbing siswa menemukan jawaban. Selain itu alasan guru tidak menggunakan tes lisan adalah karna tes lisan membutuhkan banyak waktu dalam pelaksanaanya.

Hasil penelitian ini didukung oleh penelitian yang dilakukan Suyatmini, Sarjono, Asmawati \& Rohma (2015), hasil penelitian diperoleh beberapa masalah yang dihadapi oleh guru SMK di Surakarta dalam melaksanakan kurikulum 2013 diantaranya kesulitan dalam mengatur pembelajaran kurikulum 2013, masalah dalam proses pembelajaran yang menggunakan pendekatan ilmiah dan kesulitan dalam proses penilaian autentik.

Teknik penugasan dilakukan dengan memberikan soal-soal yang harus dikerjakan secara berkelompok maupun individu. Soal diberikan dengan batas waktu pengumpulan yang telah disepakati dan nilai berdasarkan kriteria yang sudah ditetapkan. Guru berjalan ke tiap-tiap kelompok untuk mengawasi hasil pekerjaan siswa. Selain memberikan tugas di sekolah guru juga memberikan tugas untuk dikerjakan dirumah.

Dalam pelaksanaan penilaian autentik kuurikulum 2013 mata pelajaan matematika aspek keterampilan guru di SMA Negeri 2 Sukoharjo guru matematika lebih sering menggunakan teknik penilaian kinerja. Guru membagi kelompok sehingga masing-masing individu dalam kelompok harus menunjukkan kekompakannya.

Dalam penilaian keterampilan guru pernah menggunakan penilaian portopolio namun mengalami kesulitan karna tidak setiap KD dalam mata pelajaran dapat diportopoliokan. selain itu guru membuat daftar cek atau skala penilaian yang disertai dengan rubrik. Dalam penelitian yang dilakukan oleh Wolf and Stevens (2007), penggunaaan rubrik dalam kegiatan pembelajaran memiliki kemampuan dalam mengukur hasil belajar siswa dan merupakan sumber yang penting dalam perbaikan progam pembelajaran.

Selain itu dari hasil observasi yang peneliti lakukan, guru matematika menggunakan beberapa langkah dalam melakukan penilaian unjuk kerja, guru membuat rubric dan menyampaikannya kepada siswa, guru memberikan pemahaman tentang kriteria penilaian, guru menyampaikan tugas, guru memeriksa kesediaan alat dan bahan, guru membandingkan kinerja dengan rubriik penilaian, guru mencatat hasil penilaian serta mendokumentasikan hasil penilaian.

Penelitian yang dilakukan oleh Kulprasit (2016) Hasil penelitian menemukan bahwa siswa menunjukkan sikap positif dalam penulisan rubric, melalui pengalaman menulis rubric perspektif siswa dalam penilaian berdampak positif dan diarahkan untuk penilaian formative

Hasil observasi yang dilakukan di SMA Negeri 2 Sukoharjo menunjukan bahwa dalam sebuah pelaksanaan penilaian guru sudah melakukan sesuai dengan pedoman penilaian kurikulum 2013. Dalam penilaian afektif terkait sikap spiritual dan sikap sosial guru menggunakan teknik observasi dan jurnal. Lembar observasi sudah dibuat guru bersamaan dengan dibuatnya rancangan pelaksanaan pembelajaran. untuk penilaian jurnal dilakukan guru secara insidental yang artinya guru melakukan penilaian tentang tingkah laku siswa baik di dalam kelas maupun diluar kelas. Penilaian aspek pengetahuann dilakukan dengan menggunakan tes tertulis, tes lisan dan penugasan. Tes lisan hanya digunakan guru untuk mengevaluasi hasil tes tertulis ataupun penugasan. Penilaian aspek keterampilan dilakukan 
guru dengan teknik unjuk kerja. Guru membuat skala penilaian yang disertai dengan rubric.

Dalam penilaian aspek pengetahuan guru menggunakan tes tertulis, tes lisan dan penugasan. Tes lisan digunakan guru hanya digunakan guru dalam mengevaluasi tugastugas yang telah diberikan. Penelitian dilaksanakan dikelas X IPA pada materi Ekponen dan Logaritma dengan teknik ujuk kerja yang dilakukan selama waktu pembelajaran berlangsung. Dengan indikator 1.1.1. Memahami dan menunjukkan sikap bertanggung jawab, rasa ingin tahu, jujur, dan toleransi. 2.1.1 Menyebut hasil operasi aljabar dari eksponen dan logaritma. 2.1.2 Menjelaskan mengenai pengertian dan aturan dari hasil operasi aljabar eksponen dan logaritma. 2.1.3 Menerapkan unsur-unsur yang terdapat pada pengertian dan hasil operasi aljabar eksponen dan logaritma. 2.1.4 Memilah kategori dari unsur-unsur yang terdapat pada pengertian dan hasil operasi aljabar eksponen dan logaritma. 2.1.5 Merangkai unsurunsur yang sudah dikategorikan sehingga dapat dibuat kesimpulan mengenai pengertian dan aturan dari eksponen dan logaritma. Pedoman penskoran menggunakan rubrik yaitu diberi skor 4; apabila selalu melakukan sesuai pernyataan. 3; apabila sering melakukan sesuai dengan pernyataan dan kadang-kadang tidak melakukan. 2; kadang melakukan dan sering tidak melakukan. 1; apabila tidak pernah melakukan.

Hasil penelitian ini didukung dengan penelitian Wolf dan Ellen Stevan (2007) yang menyatakan bahwa penggunaan rubrik digunakan dalam menilai produk siswa dan pertunjukan sehingga dapat digunakan oleh guru dalam melakukan pembelajaran kemateri berikutnya.

Hasil penilaian ini dapat dimaknai bahwa dalam penilaian aspek keterampilan dengan teknik unjuk kerja guru seharusnya membuat daftar cek atau skala penilaian yang disertai rubrik untuk mempermudah dalam mengetahui karakteristik masing-masing peserta didik.

\section{Pemanfaatan hasil penilaian autentik mata pelajaran matematika di SMAN 2 Sukoharjo}

Berdasarkan hasil observasi guru matematika di SMA Negeri 2 sukoharjo memanfaatkan hasil penilaian autentik kurikulum 2013 untuk guru untuk membentuk sikap positif dalam pembelajaran. Hal ini sering dilakukan guru dengan membagikan dan membacakan hasil penilaian yang telah dikerjakan oleh siswa. Seperti diketahui bila seorang siswa mendapat nilai baik maka siswa lain agak berusaha untuk jadi lebih baik.

Hasil dari penilaian juga dapat membangkitkan minat dan motivasi belajar siswa. Dengan adanya persaingan yang terjadi dikelas maka motivasi belajar siswa akan naik dan tujuan dari sebuah peilaian akan tercapai. Hasil penelitian oleh Nickel (2013), menunjukkan bahwa model penilaian formatif dan sintesis dapat meningkatkan kemampuan siswa dalam menulis refleksi jurnal, penilaian formatif merupakan dasar sebelum melakukan penilaian sumatif. Penelitian lain oleh Clementsa dan Cord (2013), hasil penelitian di peroleh bahwa penilaian berbasis kerja dapat memberikan kontribusi dalam peningkatan hasil belajar siswa, melalui progam ini siswa dapat menerapkan kemampuan dalam konteks praktis serta menenerapkan pembelajaran yang diperoleh dalam dunia nyata.

Hasil dari penilaian autentik juga dimanfaatkan oleh guru dalam mengelompokan peserta didik berdasarkan prestasi masing-masing. Setelah dikelompokkan berdasarkan prestasi yang sama dalam satu kelas guru akan lebih mudah memilih metode pembelajaran yang sesuai dengan kemampuan pemahaman siswa. Pengelompokkan siswa berdasarkan hasil penilaian 
dibutuhkan guru untuk menyeragamkan siswa dengan karakteristik yang sama dalam satu kelas sehingga guru lebih mudah dalam melakukan evaluasi pembelajaran

Hasil observasi pemanfaatan hasil penilaian autentik di SMA negeri 2 sukoharjo juga digunakan sebagai informasi kepada orangtua untuk mengetahui kemajuan belajar anaknya. Hal ini dilakukan dengan memanggil orang tu dating pada saat penerimaan rapot dan memberi tahu hasil perkembangan belajar anaknya.

Kesuksesan dalam prestasi belajar siswa merupakan tanggung jawab guru dan orang tua. Peran orangtua dalam perkembangan perilaku dan cara belajar anak sangat vital, sebab anak menghabiskan banyak waktunya rumah. Orang tua berperan dalam pengawasan sikap anak dan kegiatan belajarnya dilingkungan rumah.

Guru menggunakan hasil penilaian autentik sebagai sarana perbaikan dalam rencana pelaksanaan pembelajaran. Sebab hasil dari sebuah penilaian yang dilakukan oleh guru dipengaruhi oleh berberapa faktor dan salah satu diantaranya adalah perencanaan pembelajaran, selain itu rencana pembelajaran juga merupakan bagian penting dari tugas guru selaku pengelola pembelajaran. hal ini dilakukan guru dengan mengadakan rapat evaluasi diakhir semester dengan membahas kendala-kedala yang dihadapi selama proses penilaian berlangsung.

Hasil penelitian ini sejalan dengan penelitian Merta, Suarjana dan Mahadewi (2015) yang menyimpulkan bahwa dalam tujuan pembelajaran merupakan bagian dari rencana pembelajaran sehingga diperlukan evaluasi secara berkala untuk dapat mengontrol tercapainya target pembelajaran.

Hasil penelitia ini dapat dimaknai bahwa dalam pemanfaatan hasil penilaian autentik dapat digunakan sebagai evaluasi terhadap rencana pelaksanaan dan tujuan pembelajaran yag direncanakan oleh guru, sehingga dengan dilakukan evaluasi secara berkala maka dapat dapat diketahui apakah tujuan pembelajaran tercapai atau tidak.

\section{PENUTUP}

Perencanaan penilaian autentik kurikulum 2013 mata pelajaran matematika dilakukan guru dengan berbagai langkah antara lain. melakukan langkah-langkah dalam menyususn instrument penilaian yaitu dengan menetapkan aspek-aspek yang akan diteliti, merumuskan tujuan, merumuskan indicator berdasarkan kompetensi dasar yang ada dalam silabus, dan membuat kriteria ketuntasan minimal sebagai tolak ukur hasil penilaian.

Pelaksanaan penilaian autentik kurikulum 2013 mata pelajaran matematika di awali dengan melakukan sosialisasi kepada siswa. Penilaian autentik kurikulum 2013 mata pelajaran matematika dalam aspek sikap dilakukan guru dengan teknik observasi dan teknik journal.

Penilaian aspek pengetahuan dilakukan guru dengan teknik tes tertulis, tes lisan dan penugasan. Penilaian autentik kurikulum 2013 mata pelajaran matematika dalam aspek keterampilan guru hanya menggunakan teknik unjuk kerja. Teknik unjuk kerja dilakukan guru dengan membuat daftar cek atau skala penilaian yang disertai dengan rubrik.

Pemanfaatan penilaian autentik digunakan untuk membentuk sikap positif siswa dan sebagai sarana untuk meningkatkan minat dan motivasi belajar siswa, meyeragamkan kemampuan berfikir siswa dengan cara mengelompokan peserta didik berdasarkan prestasi masing-masing, memberikan informasi kepada orangtua dalam mengetahui kemajuan 
belajar anaknya, sebagai sarana perbaikan dalam rencana pelaksanaan pembelajaran, sarana untuk mengoptimalkan proses pembelajaran yang berlangsung dalam memperbaiki proses pembelajaran sehingga siswa mencapai keberhasilan hasil belajar.

Ucapan terimakasih kami sampaikan kepada Direktorat Riset dan Pengabdian Masyarakat, Direktorat Jendral Penguatan Riset dan Pengembangan, Kementrian Riset Teknologi dan Pendidikan Tinggi, yang telah membantu dalam biaya pendanaan multitahunan melalui hibah Tim Pascasarjana. Ucapan terimakasih kami sampaikan kepada Direktur Pascasarjana dan Ketua Lembaga Penelitian UMS beserta stafnya, yang telah memberikan fasilitas dan dorongan sehingga kami bisa melakukan penelitian. Ucapan terimaksih juga kami sampaikan kepada Kepala dan Guru SMAN 2 Sukoharjo yang telah membantu proses penelitian sehingga berjalan sesuai perencanaan.

\section{DAFTAR PUSTAKA}

Almond, P. 2010. Technlogy Enabled and Universally Designed Assessment: Consedering Assess in Measuring the Achievement of Student with Disabilities a Foundation for Research. The Journal of Technology: Learning and Assessment Vol 10.

Clementsa, M. D. \& Cord, B. A. 2013. Assessment Guilding Learning: Developing Graduate Qualities in an Eksperiential Learning Progame. Assessment and Evaluation in Higher Eduacation. 2013 vol 38.

Earl, K. 2011. An-other Look at Assessment: Assessment in Learning. New Zealand Journal of Teachers' Work Volume 8.

Gao, M. 2012. Classroom Assessments in Mathematics: High School Students' Perceptions. International Journal of Business and Social Science. Vol 3. No2.

Kulprasit, W. 2016. EFL Students Attitudes Toward Authentic and Formative Assessment: The Role of Writing Rubric. International Journal of Languages, Literature, and Linguistics. Vol 2. No 1.

Kunandar. 2013. Penilaian Authentik (penilaian hasil belajar peserta didik berdasarkan kurikulum 2013). Jakarta: PT. Raja Grafindo Persada.

Merta, I. M. E. D \& Mahadewi, L. P. P. 2015. Analisis Autentik Menurut Pembelajaran Kurikulum 2013 Pada Kelas IV SD No 4 Banyuasri. e- Journal PGSD Universitas Ganesha. Vol 3 no 1 Tahun 2015.

Mulyasa. 2013. Pengembangan dan Implementasi Kurikulum 2013. Bamdung: PT. Remaja Rosdakarya.

Murdaningsih. S \& Murtiyasa, B. 2015. A Analysis Eight Grade Mathematics Text Book Of New Indonesian Curiculum (K13) Based on PISA Framework. Journal Of Research And Advances in mathematics Educattion. Vol 1. No 1. 2016.

Nickel, J. 2013. Formative Assessment and syntheses in Reflekction Journal. Reflection Journal Volume 6.3 April 2013.

Retnawati, H. Hadi, S \& Nugraha. A. C. 2016. Vocational High School Teachers' Difficulties in Implementing the Assessment in Curriculum 2013 in Yogyakarta Province of Indonesia. International Journal of Intruction. ISSN Vol 9. No 1.

Sutama, 2015. Metode peneltian pendidikan. Surkarta: Fairuz Media. 
p-ISSN: $1907-4034$

e-ISSN: 2548-6780

Sutama, Narimo, S \& Samino. 2015. Management of Curriculum 2013 Mathematic Learning Evaluation In Junior High School. International Journal Of Education. ISSN Vol 7. No 3 .

Sugiyono. 2015. Metode Penelitian Kuantitatif, Kualitatif dan $R \& D$. Bandung: Alfabeta.

Suyatmini. Sarjono, Y. Asmawati, T \& Rohmah, W. 2015. Accounting Learning Management on Curriculum 2013 Based on Lesson Study at Vocation School Surakarta. International Journal Of Education. ISSN Vol 7. No 4.

Yunus, M \& Retnowati, T H. 2014. Evaluasi Pelaksanaan Penilaian Kelas pada Mata Pelajaran Matematika SMP Negeri di Kabupaten Lombok Tengah. Jurnal Evaluasi Pendidikan Vol 2, No 22014.

Wolf, K \& Stevans, E. 2007. The Role of Rubicsin Advancing and Assessing Student Learning. The Journal of Effective Teaching. Vol 7. No1 2007. 